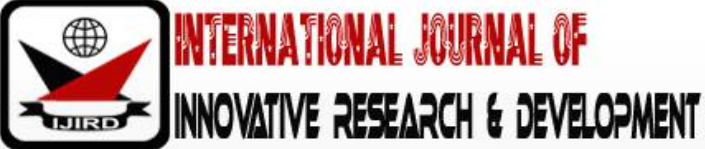

ISSN 2278 - 0211 (Online)

\section{Fire Disaster Preparedness in Accra Technical University (ATU) Ghana}

Isaac Aidoo
Lecturer, Department of Building Technology,
Accra Technical University, Accra, Ghana
Nana Benyi Ansah
Lecturer, Department of Building Technology,
Accra Technical University, Accra, Ghana
Tracy Densy
Student, Department of Building Technology,
Accra Technical University, Accra, Ghana

\section{Abstract:}

The incidence of fire outbreaks has become a common occurrence, in Ghana, there is no single day without news of a fire outbreak in some part of the country. Knowledge on fire outbreak preparedness can inform the disaster management process and lead to well-informed plans and decisions in case of fire outbreaks.

Purpose: This study was conducted to assess fire disaster preparedness in Accra Technical Universities (ATU).

Methodology: The study employed both qualitative and quantitative research approach. Primary data was collected through structured questionnaires and on-site observations. A total of 140 respondents including students, Lecturers and administrative staff and data was analyzed using SPSS version 20.0.

Findings: It emerged from the study that the level of Knowledge on the use of the fire extinguishers is very low, level of preparedness towards using the fire extinguishers is also low, staff and students in ATU are not prepared for fire disasters and there are no frequent periodic training and drills for staff and students on fire safety preparedness.

Recommendations: The study recommends regular maintenance of firefighting equipment on all blocks and offices, provision of new and state of the art firefighting equipment in all buildings and lecture halls and regular training programs on fire safety preparedness to raise the level of preparedness and awareness of staff and students on fire disaster preparedness in technical universities.

Keywords: Fire, disaster, preparedness, Accra technical universities

\section{Introduction and Background}

The increasing incidence of fire outbreaks is a global issue which has environmental and economic consequences. Fire is a possible threat to sustainable growth because of its effects on ecosystems, its contribution to carbon emissions and its impact on biodiversity (Tacconi, 2003). Fire disaster in buildings is among the known man-made disasters with the most devastating effects that cost life and properties (Shaluf 2007; Xin and Huang 2013).

Globally, many recurring fire incidences have been reported (Ibe et al., 2014). Apart from loss of property and life, fire disasters have been associated with prevalence of diseases that have been reported to contribute about $1 \%$ of the global disease burden (Leistikow et al., 2000). The most devastating effects caused by fire in buildings include the collapse of the World Trade Centre (Cowlard et al., 2013), the fire disaster in Sweden that occurred in 1998 killing 63 people (Cassuto \& Tarnow, 2003), and the Mumbai and Sharjah high-rise buildings fire incidences.

In recent years, there's been an escalation of fire outbreaks all over Ghana with very serious consequences on human life, the economy and the environment. According to the Ghana National Fire Service (GNFS), 5,531 fire outbreaks were recorded across the country, in 2018, compared to a total of 4,544 cases in 2017.The statistics indicate lives were lost through those fires, 11 more than the previous year's figure of 33. The estimated cost of damage to property as of November 2018, was over GH $\$ 28.87$ million and that of 2017, was GH\$36.28million (www.ghanabusinessnews.com). And in very recent incident, four persons were injured and several millions of monies lost during a fire outbreak that ripped through offices of the Ghana Revenue Authority (GRA) Head Office Annex on Sunday, December $1^{\text {st }} 2019$ (www.myjoyonline.com).

Disasters happen despite the best efforts of trained emergency personnel. Disasters are not bolts from the blue but a series of societal, communal, or individual mistakes, processes, and undertakings that lead to that one big disastrous event (Ishmael et al., 2015).Disaster preparedness is one of the important factors in disaster risk reduction and it encompasses community awareness, readiness to render appropriate responses and immediate recovery (Ejeta et al. 
2015). Despite its importance, less has been done globally to improve the levels of disaster preparedness (Paton, 2003). Not much has been documented on the level of readiness for fire safety in higher institutions of learning in developing nations like Ghana.

Disaster preparedness can be enhanced through strengthening community capacities, education and improving preventive mechanisms (Mathbor, 2007). Knowledge of the levels of preparedness can inform the disaster management process and lead to well-informed plans and decisions. On the other hand, a lack of disaster preparedness leads to negative economic and social consequences (Wilson et al., 2007). Preparedness is an important aspect of achieving sustainable disaster management. Disaster preparedness in this setting is determined as the steps taken to prepare for and reduce the effects of disasters. This involves prediction, where possible prevention, mitigation, appropriate responses in case of an incidence. Prevention and reduction as well as appropriate responses depend a lot on public awareness and the accessibility and condition of supportive facilities (Kihila, 2017).

Fires have also contributed to the toll of man-made disasters in Ghana with variable loss of properties and lives (Disaster Relief Emergency Fund, 2010). Instances of these fires include fire outbreaks in 2008 at various markets, especially in Accra, Kumasi and Takoradi. As well as the six (6) fire outbreaks that occurred in 2009 at markets in rural areas, with the fire at Kumasi Central Market being the most devastating (Agyakum et al., 2017).

Apart from fire outbreaks in markets, there's also been a lot fire incidence in several offices in Ghana. These include the Ministry of Information, the loading gantry of Tema Oil Refinery, offices of the Electoral Commission, and the Ridge residence of former President Rawlings and Korle-bu Teaching Hospital Central stores. Huge losses in terms of property damage and resources lost are incurred because of fires. In 2013 approximately 11,000 Ghanaians were affected by fire disasters, and the cost of these types of incidents was approximately $\$ 7$ million. Most of these fires whether domestic, industrial, institutional, commercial or vehicular come with devastating consequences, including loss of lives and properties (Addai et al., 2016).

The impact of fire disasters has been very significant in high-rise buildings because most of them are not only publicly accessed but also do accommodate many people and valuable properties (Murage, 2012). In addition, fire outbreaks in high-rise buildings have been more complex because there is rapid fire and smoke spread, difficult and sometimes, almost impossible evacuation procedures as well as the possibility of accidents (Ma \&Guo, 2012). Thus, this study will pay particular attention to public buildings, specifically, the Accra Technical University.

Most literature available high light the importance of having a set of actions in place to ensure that the fire risks in public buildings are minimized. One of the actions is the enforcement of building codes that advocates, among others, provision of facilities for firefighting to ensure compliance with all the safety requirements (Hadjisophocleous \& Benichou, 1999). Another action is imparting knowledge on the use of the installed facilities and awareness on the appropriate responses in case of fire outbreaks (Takao et al., 2004). But alas, both activities have been underrated in most of the buildings to such an extent that when fire incidences occur, people neglect to react appropriately (Kachenje et al.,2010).

Many buildings in cities in developing countries are not fitted with the necessary firefighting facilities, which indicate that enforcement of building codes is still a challenge. Surveys conducted in Ghana, Tanzania, Kenya, and Nigeria confirm that lack of availability of installations, poor conditions of the available facilities and lack of awareness among users are among the factors for high fire risks (Amoako 2014; Kachenje et al. 2010; Makachia et al.,2014; Sankey et al., 2014) as cited by Kihila,2017. This paper presents the findings from a study conducted to assess the fire disaster preparedness in Technical Universities (TU's) using Accra Technical University as a case study. Key among the objectives was assessing the level of Knowledge on the use of the fire extinguishers, level of preparedness towards using the fire extinguishers, general level of fire safety preparedness of ATU, students and staff level of satisfaction with fire safety preparedness on ATU campus, Training and drills on fire safety preparedness on campus awareness of the emergency exits on the floors of the administration block and presenting measures which students and staff recommend should be put in place to mitigate fire outbreaks in Technical Universities in Ghana.

Based on previous studies, it was established that factors, such as the presence and condition of firefighting facilities and public awareness on the use of the facilities, among others, were the important and relevant factors for the prevention of fire disasters in buildings. While the presence and condition of firefighting facilities reveal the supportive capacity of the origination, public awareness highlights the public's power to give appropriate responses in case of fire outbreak. A written report on the human awareness of fire hazards and the valuation of the preparedness are among the key components for assessing fire risks (Siu 1999).

Records show that it's human behavior that makes fire dangerous (Kobes et al. 2008, 2010). Some authors highlight the assessment of the perils and public perceptions as an indispensable factor for cutting down fire risks and that it is important to include social aspects in the provision of fire safety and management (Chow \& Hung 2010; Gwynne 2008; Ibrahim et al. 2011; Zmud 2008).

Thus, this paper offers important knowledge for users of high-rise buildings, specifically those in public institutions on how to better their fire disaster preparedness. This survey explored the availability and status of firefighting facilities; accessibility to available facilities; awareness of presence and localization of escape ways; knowledge on how to control facilities; frequency of trainings and fire drills; the level of consciousness on the use of these facilities and the ability to appropriately react in event of fire outbreak.

\section{Brief History of Accra Technical University}

Established in 1949 as a Technical School and commissioned in 1957 as a Technical Institute, Accra Technical University then (Accra Technical Institute) became the first Technical University to be established in Ghana. In 1963 the Institute assumed a new name as Accra Polytechnic under the directions of President Dr. Kwame Nkrumah to be a key 
driver of the country's industrialization process. Following the operationalization of the PNDC Law of 1992 (PNDC 321) in 1993/1994, the Polytechnic gained tertiary recognition.

The elevation provided that the University under the Higher Education Council was vested with the autonomy to award Higher National Diploma (HND) through the National Board for Professional and Technical Examination (NABPTEX). With the coming into force of the Polytechnic Act (Act 745) in 2007, the PNDC Law 321 of 1992 was repealed to allow polytechnics the autonomy to award Higher National Diplomas (HND), Diplomas, Certificates and other degrees that the Polytechnic may deem appropriate, all accredited by the National Accreditation Board.

The Technical University Act, 2016, (Act 922) converted together with 8 other Polytechnics, Accra Polytechnic to Accra Technical University, giving it a Technical University status. The elevation was aimed at enhancing technical training with emphasis on producing world-class graduates molded in excellence and professionalism in diverse technical programs in theory and in practice.

Currently, the University has 5 faculties - Faculty of Engineering, Faculty of Built Environment, Faculty of Applied Sciences, Faculty of Applied Arts, and Faculty of Business and other 16 departments.

The University has a staff of about 700 made up of faculty, senior members, senior administrative officers and other supporting staff and a student population of about 15,000 made up of full and part time students taking various academic and professional programs (Accra Technical University's official website, 2019).

Some of the questions the research addressed are: what is the knowledge on the use of the fire extinguishers; what is the Level of preparedness towards using fire extinguishers; general level of fire safety preparedness of ATU; Level of satisfaction with fire safety preparedness on ATU campus; Training and drills on fire safety preparedness on campus; Awareness of the emergency exits on the floors of the administration block.

\section{Methodology}

This study employed the qualitative and quantitative research approach. Primary data was collected through questionnaires and on-site observations. A total of 140respondents; including teaching and non-teaching staff were sampled for this study. The buildings selected for observation included Electrical/Electronic Block, Fashion Block, Office Complex, Workshops/ Small Classrooms, Auditorium/HCIM Block, Old Hostel, New Hostel, Canteen Block, SRC Complex, KBlock, N- Block, B-Tech Block, Administration Block, Science laboratory Block, Quality Assurance Block, Building/Civil Department, Exams Department, School Clinic, Printing Press, Workers' Office (next to press), and the Security Guard's Post. These buildings were selected because they harbour a large number of people and properties and also the fact that whenever there's a fire outbreak, the impact on such buildings are always high. Data was analyzed using SPSS version 20.0.

\subsection{Data Collection Methods and Analysis}

Data was collected using structured questionnaires administered to students, teaching and non-teaching and administration staff. Field observations accompanied by photographic recording were employed to substantiate the information collected.

\subsection{Results and Discussion}

All the selected buildings were story buildings with the number of stories ranging from 2 to 5 stories. The oldest buildings are the workshops (Mechanical, civil lab, Furniture workshop and old hostel). The findings show that, not all the buildings visited had the required fire-fighting equipment. However, those having fire-fighting equipment are either not functioning, not serviced or is broken down. See Table 1.

\subsection{Composition of Respondents}

A total of 140 respondents including students, teaching and Non-Teaching staff were selected for the study. Of the 140 selected, 124 respondents representing $88.6 \%$ answered and returned their questionnaires. Out of the 124 respondents, 96 representing $77.4 \%$ were students (level 100-Level 400) and 24 respondents representing 19.4\% were teaching and non-teaching staff. Of the respondents, $35.8 \%$ were female and $63.4 \%$ male. One respondent representing $0.8 \%$ failed to answer on gender.

\subsection{Level of Knowledge on the Use of the Fire Extinguishers}

The study explored respondent's level of knowledge on the function of the fire extinguishers. The response are as follows, twenty-three respondents representing $18.7 \%$ have no knowledge on the use of the fire extinguishers, thirty-five respondents representing $28.5 \%$ have slight knowledge about its usage, thirty- six respondents representing $29.3 \%$ possess a moderate knowledge and fourteen respondents representing $11.4 \%$ have high knowledge about the use of the fire extinguishers. This clearly indicates that very few students and staff of the ATU have knowledge about the use of the fire extinguishers.

\subsection{Level of Preparedness towards Using the Fire Extinguishers}

On the question of the Level of preparedness towards using the fire extinguishers, 38 respondents representing $30.9 \%$ are not prepared for the use of the fire extinguishers, 19 respondents representing 15.4 are slightly prepared whilst 25 respondents representing $20.3 \%$ and 17 respondents representing $13.8 \%$ are moderately and highly prepared respectively. 


\subsection{General Level of Fire Safety Preparedness of ATU}

On the general level of fire safety preparedness at ATU,40 respondents representing 32.5\% said they are not prepared for fire safety, 35 respondents representing $28.5 \%$ are slightly prepared whereas 16 respondents representing $13 \%$ and 5 respondents representing $4.1 \%$ are moderately and highly prepared. This clearly shows that should there be any fire disaster, it will have catastrophic consequences on ATU.

\subsection{Level of Satisfaction with Fire Safety Preparedness on ATU Campus}

On the question of the level of satisfaction with fire safety preparedness on ATU campus, 37 respondents representing $30.1 \%$ are not satisfied, 36 respondents representing $29.3 \%$ are fairly dissatisfied, 17 respondents presenting $13.8 \%$ are fairly satisfied and only 3 respondents representing $2.4 \%$ are very satisfied.

\subsection{Awareness of the Emergency Exits on the Floors of the Administration Block}

On awareness of emergency exits along the floors of the administration block, 17 respondents representing $13.8 \%$ are aware whereas 72 respondents representing 58.5\% stated they are not aware of the emergency exit and 29 respondents representing $23.6 \%$ are uncertain. This clearly suggests the need to create the awareness of the various emergency exits in the buildings.

\subsection{Training and Drills on Fire Safety Preparedness on Campus}

On the question of how often respondents are given training and drills on fire safety preparedness on ATU campus, 102 respondents representing $82.9 \%$ were very emphatic that no training and fire drills are conducted at all. This is a very serious form of negligence that needs to be corrected urgently.

\subsection{Fire Hazard Situational Analysis / Available Firefighting Equipment Conditions}

Situational analysis of the buildings revealed that most of the buildings lack the necessary means and equipment for firefighting. For instance, it was clear that the buildings had non-functioning firefighting facilities. Furthermore, the buildings had only four identifiable fire assembly points (Table 1).

\begin{tabular}{|c|c|c|c|c|c|c|c|c|c|}
\hline \multirow[b]{2}{*}{$\mathrm{S} / \mathrm{N}$} & \multirow[b]{2}{*}{ BUILDING } & \multirow[b]{2}{*}{ FLOORS/LOCATIONS } & \multicolumn{4}{|c|}{ FIRE SAFETY DEVICES/EQUIPMENT } & \multirow[b]{2}{*}{$\begin{array}{l}\text { Call } \\
\text { Points }\end{array}$} & \multirow[b]{2}{*}{$\begin{array}{c}\text { Assembly } \\
\text { points }\end{array}$} & \multirow[b]{2}{*}{ Remarks } \\
\hline & & & \begin{tabular}{c|} 
Fire \\
Extinguishers
\end{tabular} & \begin{tabular}{|c|} 
Fire \\
Extinguishers \\
Review
\end{tabular} & $\begin{array}{c}\text { Smoke } \\
\text { Detectors }\end{array}$ & $\begin{array}{c}\text { Fire } \\
\text { Alarms }\end{array}$ & & & \\
\hline \multirow{5}{*}{1} & \multirow{5}{*}{$\begin{array}{l}\text { Electrical/Electronic } \\
\text { Block }\end{array}$} & Ground Floor & 4 & 3 & 7 & 3 & 3 & Yes & \\
\hline & & 1 st Floor & 1 & 2 & 8 & 4 & 3 & & \\
\hline & & 2nd Floor & 1 & 3 & 6 & 4 & 2 & & \\
\hline & & 3rd Floor & Non & 2 & 8 & 4 & 4 & & \\
\hline & & 4th Floor/ Great Hall & Non & 2 & 8 & 4 & 4 & & \\
\hline \multirow{4}{*}{2} & \multirow{4}{*}{ Fashion Block } & Ground Floor & 1 & 2 & 10 & 2 & 2 & Yes & \\
\hline & & 1st Floor & 1 & 2 & 12 & 2 & 2 & & \\
\hline & & 2nd Floor & 3 & 3 & 12 & 2 & 1 & & \\
\hline & & 3rd Floor & 1 & 2 & 8 & 1 & 2 & & \\
\hline \multirow{4}{*}{3} & \multirow{4}{*}{ Office Compex } & Ground Floor & 4 & 4 & 23 & 2 & 2 & Yes & \\
\hline & & 1st Floor & 4 & 4 & 23 & 2 & 2 & & \\
\hline & & 2nd Floor & 4 & 4 & 23 & 2 & 2 & & \\
\hline & & 3rd Floor & 4 & 4 & 23 & 2 & 2 & & \\
\hline \multirow{9}{*}{4} & \multirow{9}{*}{$\begin{array}{l}\text { Workshops/Small } \\
\text { Classrooms }\end{array}$} & Offices and Classrooms Attached & Non & & Non & Non & Non & Yes & \\
\hline & & Refridgeration Shop & 2 & 2 & Non & Non & Non & & \\
\hline & & Furniture Workshop & 1 & 2 & Non & Non & Non & & \\
\hline & & \begin{tabular}{|l} 
Welding Workshop \\
\end{tabular} & Non & 2 & Non & Non & Non & & \\
\hline & & Mechanical Lab \& Dept & 1 & 3 & Non & Non & Non & & \\
\hline & & Auto mechanics Workshop & 2 & 2 & Non & Non & Non & & \\
\hline & & Mechanical Workshop & 2 & 2 & Non & Non & Non & & \\
\hline & & CBT Lab & 1 & 1 & Non & Non & Non & & \\
\hline & & Building Labs & 2 & 2 & Non & Non & Non & & \\
\hline \multirow{3}{*}{5} & \multirow{3}{*}{ Auditorium/Hcim Block } & Auditorium & 2 & 2 & Non & Non & Non & Yes & \\
\hline & & HCIM Ground Floor & 1 & 3 & Non & Non & Non & & \\
\hline & & HCIM 1st Floor & Non & 2 & Non & Non & Non & & \\
\hline \multirow{6}{*}{6} & \multirow{6}{*}{ Old Hostel } & Ground Floor & 4 & 3 & Non & Non & Non & Yes & \\
\hline & & 1st Floor & Non & 2 & Non & Non & Non & & \\
\hline & & 2nd Floor & 1 & 2 & Non & Non & Non & & \\
\hline & & 3rd Floor & 1 & 2 & Non & Non & Non & & \\
\hline & & 4th Floor & 1 & 2 & Non & Non & Non & & \\
\hline & & 5th Floor & Non & 2 & Non & Non & Non & & \\
\hline & & Ground Floor & 2 & 2 & 24 & 3 & 3 & Yes & \\
\hline & & 1st Floor & Non & 2 & 32 & 3 & 3 & & \\
\hline 7 & New Hostel & 2nd Floor & Non & 2 & 32 & 3 & 3 & & Administration. \\
\hline & & 3rd Floor & 1 & 2 & 32 & 3 & 3 & & Not Working. \\
\hline & & 4th Floor & 1 & 2 & 32 & 3 & 3 & & \\
\hline & & 5th Floor & 1 & 2 & 30 & 3 & 3 & & \\
\hline & & Ground Floor/Canteen & Non & 2 & Non & Non & Non & Yes & \\
\hline & & 1st Floor & Non & 2 & Non & Non & Non & & \\
\hline 8 & Offices/Canteen Block & 2nd Floor & Non & 2 & Non & Non & Non & & \\
\hline & & 3 rd Floor & Non & 3 & Non & Non & Non & & \\
\hline & & 4th Floor & Non & 2 & Non & Non & Non & & \\
\hline & & Ground Floor & 1 & 2 & Non & Non & Non & Yes & \\
\hline 9 & SRC Complex & 1st Floor & 2 & 2 & Non & Non & Non & & \\
\hline 3 & Snceomingex & 2nd Floor & 1 & 2 & Non & Non & Non & & \\
\hline & & 3rd Floor & Non & 2 & Non & Non & Non & & \\
\hline & & Ground Floor & Non & 2 & Non & Non & Non & & \\
\hline 10 & K- Block & 1st Floor & 1 & 2 & Non & Non & Non & & \\
\hline & & 2nd Floor & 1 & 2 & Non & Non & Non & & \\
\hline
\end{tabular}




\begin{tabular}{|c|c|c|c|c|c|c|c|c|c|}
\hline \multirow[b]{2}{*}{$S / N$} & \multirow[b]{2}{*}{ BUILDING } & \multirow[b]{2}{*}{ FLOORS/LOCATIONS } & \multicolumn{4}{|c|}{ FIRE SAFETY DEVICES/EQUIPMENT } & \multirow[b]{2}{*}{$\begin{array}{c}\text { Call } \\
\text { Points }\end{array}$} & \multirow[b]{2}{*}{$\begin{array}{c}\text { Assembly } \\
\text { points }\end{array}$} & \multirow[b]{2}{*}{ Remarks } \\
\hline & & & \begin{tabular}{|c|} 
Fire \\
Extinguishers
\end{tabular} & \begin{tabular}{|c|} 
Fire \\
Extinguishers \\
Review
\end{tabular} & \begin{tabular}{|c|} 
Smoke \\
Detectors
\end{tabular} & $\begin{array}{c}\text { Fire } \\
\text { Alarms }\end{array}$ & & & \\
\hline \multirow{3}{*}{11} & \multirow{3}{*}{ N-Block } & Ground Floor & Non & 2 & Non & Non & Non & Yes & \\
\hline & & 1st Floor & 1 & 2 & Non & Non & Non & & \\
\hline & & 2nd Floor & 3 & 3 & Non & Non & Non & & \\
\hline \multirow{5}{*}{12} & \multirow{5}{*}{ B-Tech Block } & Ground Floor & 3 & 3 & Non & Non & Non & Yes & \\
\hline & & 1st Floor & Non & 2 & Non & Non & Non & & \\
\hline & & 2nd Floor & 1 & 2 & Non & Non & Non & & \\
\hline & & 3rd Floor & 3 & 1 & Non & Non & Non & & \\
\hline & & Stores & 2 & 2 & Non & Non & Non & & \\
\hline \multirow{4}{*}{13} & \multirow{4}{*}{ Administration Block } & Ground Floor & 2 & 4 & 9 & 2 & 2 & Yes & \multirow{6}{*}{$\begin{array}{l}\text { Control Panel in } \\
\text { Administration } \\
\text { Not Working }\end{array}$} \\
\hline & & 1st Floor & 1 & 4 & 2 & 5 & Non & & \\
\hline & & 2nd Floor & 2 & 4 & 14 & 3 & 4 & & \\
\hline & & 3rd Floor & 2 & 4 & all offices & 3 & 3 & & \\
\hline \multirow{3}{*}{14} & \multirow{3}{*}{ SLT/Sec \& Mgt Block } & Ground Floor & 4 & 5 & \begin{tabular}{|l|} 
Non \\
\end{tabular} & Non & Non & Yes & \\
\hline & & 1st Floor & 2 & 3 & Non & Non & Non & & \\
\hline & & 2nd Floor & 3 & 2 & Non & Non & Non & & \\
\hline \multirow{3}{*}{15} & \multirow{3}{*}{ Quality Assurance Block } & Ground Floor & 1 & 1 & Non & Non & Non & & \\
\hline & & 1st Floor & 1 & 1 & Non & Non & Non & & \\
\hline & & Sanitation office & Non & 1 & Non & Non & Non & & \\
\hline 16 & \begin{tabular}{|c|} 
Environmental \\
Department (Beside bus \\
park)
\end{tabular} & Environmental Dept. & 1 & 1 & Non & Non & Non & & \\
\hline \multirow{3}{*}{17} & \multirow{3}{*}{$\begin{array}{l}\text { Building/Civil } \\
\text { Department }\end{array}$} & Ground Floor & 1 & 1 & Non & Non & Non & & \\
\hline & & 1st Floor & 1 & 1 & Non & Non & Non & & \\
\hline & & Student's Loan office & Non & 1 & Non & Non & Non & & \\
\hline \multirow{3}{*}{18} & & Ground Floor & 1 & 1 & Non & Non & Non & & \\
\hline & Old Exams Department & 1st Floor & 2 & 1 & Non & Non & Non & & \\
\hline & & Purhasing and Supply Dept & 1 & 1 & Non & Non & Non & & \\
\hline 19 & School Clinic & School Clinic & 2 & 2 & Non & Non & Non & Yes & \\
\hline 20 & Printing Press & Printing Press & Non & 1 & Non & Non & Non & & \\
\hline 21 & \begin{tabular}{|c|}
$\begin{array}{c}\text { Cleaner's Office (next to } \\
\text { press) }\end{array}$ \\
\end{tabular} & Workers' Office & Non & 1 & Non & Non & Non & & \\
\hline 22 & Security Guard's Post & Container Office & 2 & 2 & Non & Non & Non & & \\
\hline 23 & Masjid & Prayer room & Non & 0 & Non & Non & Non & & \\
\hline 24 & DEM BIOCK & FIRST FLOOR & & 2 & Yes & Yes & Yes & Yes & \\
\hline 25 & & SECOND FLOOR & & 1 & Yes & Yes & Yes & & \\
\hline 26 & & GROUND FLOOR & & 2 & Yes & Yes & Yes & Yes & \\
\hline 27 & GUEST HOUSF (ATU) & FIRST FLOOR & & 2 & Yes & Yes & Yes & & \\
\hline 28 & ) & SECOND FLOOR & & 2 & Yes & Yes & Yes & & \\
\hline 29 & & THIRD FLOOR & & 2 & Yes & Yes & Yes & & \\
\hline 31 & NEW I.C.T BLOCK & BASEMENT & Non & 2 & Yes & Yes & Yes & Yes & \\
\hline 32 & & GROUND FLOOR & Non & 2 & Yes & Yes & Yes & & \\
\hline 33 & & FIRST FLOOR & Non & 2 & Yes & Yes & Yes & & \\
\hline 34 & & SECOND FLOOR & Non & 2 & Yes & Yes & Yes & & \\
\hline 35 & & THIRD FLOOR & Non & 2 & Yes & Yes & Yes & & \\
\hline 36 & FURNITURE SHOP & & 2 & 2 & Yes & Yes & Yes & & \\
\hline 37 & \begin{tabular}{|l|} 
UPOLSTRYAND \\
FURNITURE
\end{tabular} & & 1 & 1 & Yes & Yes & Yes & & \\
\hline
\end{tabular}

Table 1: A Field Study of Fire Safety Equipment in Various Buildings at ATU Source: Field Study, 2020

This suggests that fire preparedness is given low priority or no priority at all in Accra Technical University. Installation of basic firefighting facilities is a requirement by the existing legislation and building codes that requires all public institutions are equipped with firefighting facilities. The observed situation indicates that there is non-adherence and negligence to comply with the regulations. Factors for negligence need to be further studied. Knowledge on such underlying factors can supplement the information obtained from this study and be used for setting proper fire safety management strategy for ATU as well as other institutions.

\subsection{Measures to Mitigate Fire Outbreaks in Public Universities}

The findings of the study revealed that all the identified fire outbreak mitigation measures are important since all the mean scores are greater than 3.5. From Table 2, Repairs of all damaged electrical sockets and switches in lecture rooms and offices was the most significant fire mitigation measure needed in the ATU. This factor was ranked as the highest as it had a mean value of 4.55 with a corresponding standard deviation of 0.89 . Neglecting to fix them poses danger to the users.

Regular inspection and maintenance of firefighting equipment was ranked as the second fire mitigation measure that can be enforced to prevent possible fire outbreak. Prevention, it is said, is always better than cure. Replacement of all non-functioning smoke detectors and other firefighting equipment was one of the mitigation measures strongly agreed upon by respondents to control fire outbreak in ATU and was ranked third. Provision of emergency communication systems and Public education on fire safety were ranked fourth and fifth respectively.

Considering the nature of the fire situation in Ghana, Addai et al. (2016) suggested that the issue of public education on fire outbreaks and its prevention should be intensified within the country. This suggestion should also be extended to public universities in Ghana. University authorities should from time to time invite the Ghana National Fire Service and the National Disaster Management Organization to conduct an intensive educational campaign among the students and lecturers with regards to fire prevention and safety measures, because studies have shown that most fires actually occur out of ignorance and negligence on the part of the occupants. 
Enforcement of fire safety policies was identified by respondents as one of the most significant fire safety measures that should be put in place in ATU to control the outbreak of fires. This can be carried out by ensuring that fire safety regulations are consistently followed throughout the country; this includes the Accessibility to fire hydrants, Fire evacuation plans, creation of more fire assembly points, provision of fire insurance policies and regular fire drills for staff and students.

\begin{tabular}{|c|c|c|c|c|}
\hline Item No. & Mitigation Measures (Variables) & Mean & STD & Ranking \\
\hline 1 & $\begin{array}{c}\text { Repairs of all damaged electrical sockets and switches in } \\
\text { lecture rooms and offices }\end{array}$ & 4.55 & 0.89 & $1^{\text {st }}$ \\
\hline 2 & Regular inspection and maintenance firefighting equipment & 4.45 & 0.91 & $2^{\text {nd }}$ \\
\hline 3 & $\begin{array}{c}\text { Replacement of all non-functioning smoke detectors and } \\
\text { other firefighting equipment }\end{array}$ & 4.41 & 1.07 & $3^{\text {rd }}$ \\
\hline 4 & Provision of emergency communication systems & 4.35 & 0.93 & $4^{\text {th }}$ \\
\hline 5 & Public education on fire safety & 4.33 & 1.14 & $5^{\text {th }}$ \\
\hline 6 & Enforcement of fire safety policies & 4.29 & 1.05 & $6^{\text {th }}$ \\
\hline 7 & Accessibility to fire hydrants & 4.25 & 0.88 & $7^{\text {th }}$ \\
\hline 8 & Fire evacuation plans & 4.22 & 1.00 & $8^{\text {th }}$ \\
\hline 9 & Existence of fire assembly points & 4.19 & 0.99 & $9^{\text {th }}$ \\
\hline 10 & Provision of fire Insurance policies & 4.15 & 1.03 & $1^{\text {th }}$ \\
\hline 11 & Regular Fire drills for staff and students & 4.15 & 1.05 & $1^{\text {th }}$ \\
\hline
\end{tabular}

Table 2: Descriptive Statistics of Measures for Mitigating Fire Outbreaks

Source: Field Data 2020

\section{Conclusion}

It is a fact of life that disasters can happen anytime and cause loss of lives and properties. This study was undertaken to assess fire disaster preparedness in technical universities in Ghana using Accra Technical University as a case study.

In the case of dealing with fire disaster preparedness in technical universities in Ghana, the level of Knowledge on the use of the fire extinguishers is very low, level of preparedness towards using the fire extinguishers is low, staff and students in ATU are not prepared in case of fire disaster, students and staff are not satisfied with the level of fire safety preparedness on ATU campus, there are no periodic training and drills for staff and students on fire safety preparedness on campus, and no creation of awareness on emergency exits on the floors of the administration block.

Empirically, this research has revealed that there is almost no fire safety disaster preparedness among staff and students in ATU. Generally, fire disaster preparedness lies in the hands of university authorities and government has the sole responsibility of putting, enacting and enforcing the law and in order to safeguard staff and students.

It is therefore important from this study that repairs of all damaged electrical sockets and switches in lecture rooms and offices, regular inspection and maintenance of firefighting equipment, replacement of all non-functioning smoke detectors and other firefighting equipment, provision of emergency communication systems and public education on fire safety among others are put in place to ensure a fire free academic environment for staff and students to operate in.

\section{Recommendations}

Based on the findings, fire disasters preparedness for ATU is a challenge. To correct this situation, the authors recommend that there should be some measures put in place to ensure holistic adherence to fire regulations and fire safety disaster preparedness by managers of the Accra Technical University. There must be a strong collaboration between ATU authorities and Ghana National Fire service to strengthen the enforcement of fire laws and a very effective monitoring process must be put in place. The following recommendation should be considered; implementation of regular maintenance schedules to ensure that the firefighting equipment are in good condition on all blocks and offices, provision of new and state of the art firefighting equipment in all buildings and lecture halls, conduct regular training programs on fire safety preparedness to raise the level of preparedness and awareness of staff and students on fire disaster preparedness in technical universities, estate department in collaboration with the Ghana National Fire service should replace all non-functioning fire equipment in ATUand increase their level of knowledge and awareness on fire disaster preparedness.

\section{References}

i. Agyekum K, Ayarkwaand Opoku J. Fire Safety Preparedness in The Central Business District of Kumasi, Ghana. Asian Journal of Science and Technology Vol. 08, Issue, 01, pp.4169-4175, January, 2017

ii. Annan J-S, Addai EK, Tulashie SK. A call for action to improve occupational health and safety in Ghana and a critical look at the existing legal requirement and legislation. Saf Health Work 2015; 6:146e50.

iii. Amoako, T., 2014, 'Assessment of domestic fire management in Kumasi Metropolis', B.A (Integrated Development Studies), Kwame Nkrumah University of Science and Technology.

iv. Chow, W.K. \& Hung, W.Y., 2010, 'Scheme for determining additional fire safety provisions for tall buildings', Journal of Applied Fire Science 19, 341-367. http://dx.doi.org/10.2190/AF.19.4.d 
v. Cowlard, A., Bittern, A., Abecassis-Empis, C. \& Torero, J., 2013, 'Fire safety design for tall buildings', Procedia Engineering 62, 169-181. http://dx.doi.org/10.1016/j.proeng.2013.08.053

vi. Cassuto, J. \& Tarnow, P., 2003, 'The discotheque fire in Gothenburg 1998: A tragedy among teenagers', Burns 29, 405-416. http://dx.doi.org/10.1016/S03054179(03)00074-3

vii. Emmanuel K. Addai, Samuel K. Tulashie, Joe-Steve Annan, Isaac Yeboah, 2016. Trend of Fire Outbreaks in Ghana and Ways to Prevent These Incidents

viii. Ghana National Fire Service Ghana National Fire Service Act, 1997 [Internet]. 2014 [cited 2014 Jan 6].

Available from: http://www.epa.gov.gh/ghanalex/acts/ Acts/GHANA\%20NATIONAL\%20FIRE\%20SERVICE\%20ACT, 1997.pdf.

ix. Hadjisophocleous, G.V. \& Benichou, N., 1999, 'Performance criteria used in fire safety design', Automation in Construction 8, 489-501. http://dx.doi.org/10.1016/S0926-5805(98)00096-X

x. Kihila, J.M., 2017, 'Fire disaster preparedness and situational analysis in higher learning institutions of Tanzania', Jàmbá: Journal of Disaster Risk Studies 9(1), a311. https://doi.org/10.4102/jamba.v9i1.311

xi. Kukali, A.N. \&Kabuka, E.K., 2009, 'Fire disasters in secondary boarding schools in Kenya', Journal of Disaster Management and Risk Reduction 3, 60-71.

xii. Mathbor, G.M., 2007, 'Enhancement of community preparedness for natural disasters: The role of social work in building social capital for sustainable disaster relief and management', International Social Work 50, 357369. http://dx.doi.org/10.1177/0020872807076049

xiii. Miceli, R., Sotgiu, I. \&Settanni, M., 2008, 'Disaster preparedness and perception of flood risk: A study in an alpine valley in Italy', Journal of Environmental Psychology 28, 164-173. http://dx.doi.org/10.1016/j.jenvp.2007.10.006

xiv. Murage, J.G., 2012, Factors influencing fire disaster preparedness in the central business District of Nyeri town, Nyeri county, Project Planning and Management, University of Nairobi, Nairobi.

xv. Miceli, R., Sotgiu, I. \&Settanni, M., 2008, 'Disaster preparedness and perception of flood risk: A study in an alpine valley in Italy', Journal of Environmental Psychology 28, 164-173. http://dx.doi.org/10.1016/j.jenvp.2007.10.006

xvi. Ma, Q. \&Guo, W., 2012, 'Discussion on the fire safety design of a high-rise building', Procedia Engineering 45, 685-689. http://dx.doi.org/10.1016/j.proeng.2012. 08.223

xvii. Paton, D., 2003, 'Disaster preparedness: A social cognitive perspective', Disaster Prevention and Management: An International Journal 12, 210-216. http://dx.doi.org/10.1108/09653560310480686

xviii. Srinivas, H. \& Nakagawa, Y., 2008, 'Environmental implications for disaster preparedness: Lessons learnt from the Indian Ocean Tsunami', Journal of Environmental Management 89, 4-13.

http://dx.doi.org/10.1016/j.jenvman. 2007.01.054

xix. Shaluf, I.M., 2007, 'An overview on disasters', Disaster Prevention and Management: An International Journal 16, 687-703. http://dx.doi.org/10.1108/0965356071 0837000

xx. Tulashie SK, Addai EK, Annan J-S. Exposure assessment, a preventive process in managing workplace safety and health, challenges in Ghana. SafSci2016; 84:210e5.

xxi. Tacconi, L. 2003. Fires in Indonesia: Causes, Costs and Policy Implications. Center for International Forestry Research.

xxii. Victoria, L. W. 2003. Community Based Approaches to Disaster Mitigation. Philippines.

xxiii. (https://www.ghanabusinessnews.com, accessed on $2^{\text {nd }}$ December, 2019)

xxiv. Norman, I. D., Awiah, B. M., Aikins, M. K., \& Binka, F. N. (2015). Review of Catastrophic Fires and Risk Communication, Ghana. Advances in Applied Sociology, 5, 167-177.

http://dx.doi.org/10.4236/aasoci.2015.55016 